Proc. Estonian Acad. Sci. Biol. Ecol., 2003, 52, 3, 268-283

\title{
How are the zebra mussels doing in the Gulf of Finland?
}

\author{
Alexander E. Antsulevich ${ }^{\mathrm{a}}$, Pentti Välipakka ${ }^{\mathrm{b}}$, and Juhani Vaittinen ${ }^{\mathrm{c}}$ \\ a Department of Hydrobiology and Ichthyology, St. Petersburg State University, 16 Liniya, 29, \\ St. Petersburg, 199178, Russia \\ b Southeast Finland Regional Environmental Center, Kouvola, Finland; Pentti.Valipakka@ymparisto.fi \\ c ESOX-video Ltd., Kotka, Finland; juhani.vaittinen@luukku.com
}

Received 14 January 2003, in revised form 24 March 2003

\begin{abstract}
The zebra mussel (Dreissena polymorpha) was first found in the Gulf of Finland only in 1990. Its distribution, abundance, ecology, and growth rate were studied in this area using SCUBA diving. The growth rate of juveniles and adults was studied by direct observations in the nature on artificial substrates and by reconstructing the linear growth from annual rings. Growth rate analysis was performed for five local populations dispersed widely in both the Finnish and Russian parts of the Gulf of Finland. It was found that the dispersal of zebra mussels to the west of the gulf is limited by the average salinity level of 5 PSU. During the last decade, the abundance of the mussels increased from one to two orders of magnitude. The growth rate of the zebra mussels in the Gulf of Finland is probably the lowest worldwide.
\end{abstract}

Key words: zebra mussel, Dreissena polymorpha, Gulf of Finland, growth rate, ecology.

\section{INTRODUCTION}

The zebra mussel (Dreissena polymorpha (Pallas)) is a Ponto-Caspian species by origin. Since the beginning of the 19th century it started to spread very rapidly and by the 20th century the species was widely distributed within the fresh and brackish waters of Europe and even North America (Strayer, 1991; Schloesser et al., 1994; Starobogatov, 1994). However, for a long period of time these very common mussels were unknown in the Gulf of Finland (Järvekülg, 1979; Leppäkoski, 1984), where they appeared in the 1980s [?] and were first found only in 1990 (Antsulevich \& Lebardin, 1990; Antsulevich \& Chiviliov, 1992; Valovirta \& Porkka, 1996; Välipakka et al., 1997).

\footnotetext{
* Corresponding author, hydra@AA1079.spb.edu
} 
The appearance of this immigrant species in the fauna of Finland can have several important ecological and practical consequences. Dreissena is a very active fresh- and brackish-water biofouler and filtrator. Its influence and practical importance can be both strongly negative and positive depending on the situation and the mollusc's abundance. It can bring serious damage to various runningwater, water-supply, or cooling systems. On the other hand, the zebra mussel can enhance aquatic ecosystems. It is an additional source of food for fish and marine birds, and aggregations of mussels can be used for water quality management (Mikheev, 1967; L'vova-Katchanova, 1971; Reeders \& bij de Vaate, 1990; Reeders et al., 1993; Smit et al., 1993; Anon., 1994; Antsulevich, 1994; Antsulevich et al., 2000).

In the northern part of the Gulf of Finland, D. polymorpha inhabits areas with what are considered extreme environmental conditions for this species. This causes some peculiarities in its ecology. The knowledge of the ecology and biology of this species in the newly-invaded area is very important to make the following events predictable.

\section{MATERIALS AND METHODS}

Zebra mussels inhabit only hard bottoms or other hard substrates, very often attaching to vertical rocks or sheltering themselves inside natural hollows. That is why SCUBA diving is the most appropriate way for collecting samples and studying them.

In Finnish waters material was collected during several expeditions on the training vessel Katarina, motorboats Tiina and Kyvetti, and sailing boat Sinituulia, carried out during 1995-2002. To verify the possible methods of Dreissena penetration into Finnish waters, research in the nearby areas of the Russian part of the gulf was needed. For this reason, a special cruise aboard the sailing catamaran Orients with an international team of divers was undertaken. The wide Russian coastal area of the gulf and its islands were observed by several shorter expeditions using various vessels. The area of investigations is shown in Fig. 1. Additional comparative material was collected in the mouth of the Severnaya Dvina River (White Sea area), near the city of Arkhangel'sk.

The best way to answer the question, "How is the zebra mussel doing in the Gulf of Finland?" is to study the main structural parameters of the population and the individual growth rate of the molluscs of the local settlements.

Quantitative studies by sampling or calculations directly under the water were made with frames of 0.25 and $1 \mathrm{~m}^{2}$ or along bottom transects, depending on the mussels' density and water transparency. The structure of the Dreissena population from various sites of the Gulf of Finland was studied by measuring and scaling the mussels. In total, about 2000 specimens were investigated.

Dreissena's spat settling, abundance, and the growth rate of juveniles were studied by special underwater experiments employing artificial reefs (AR) made 


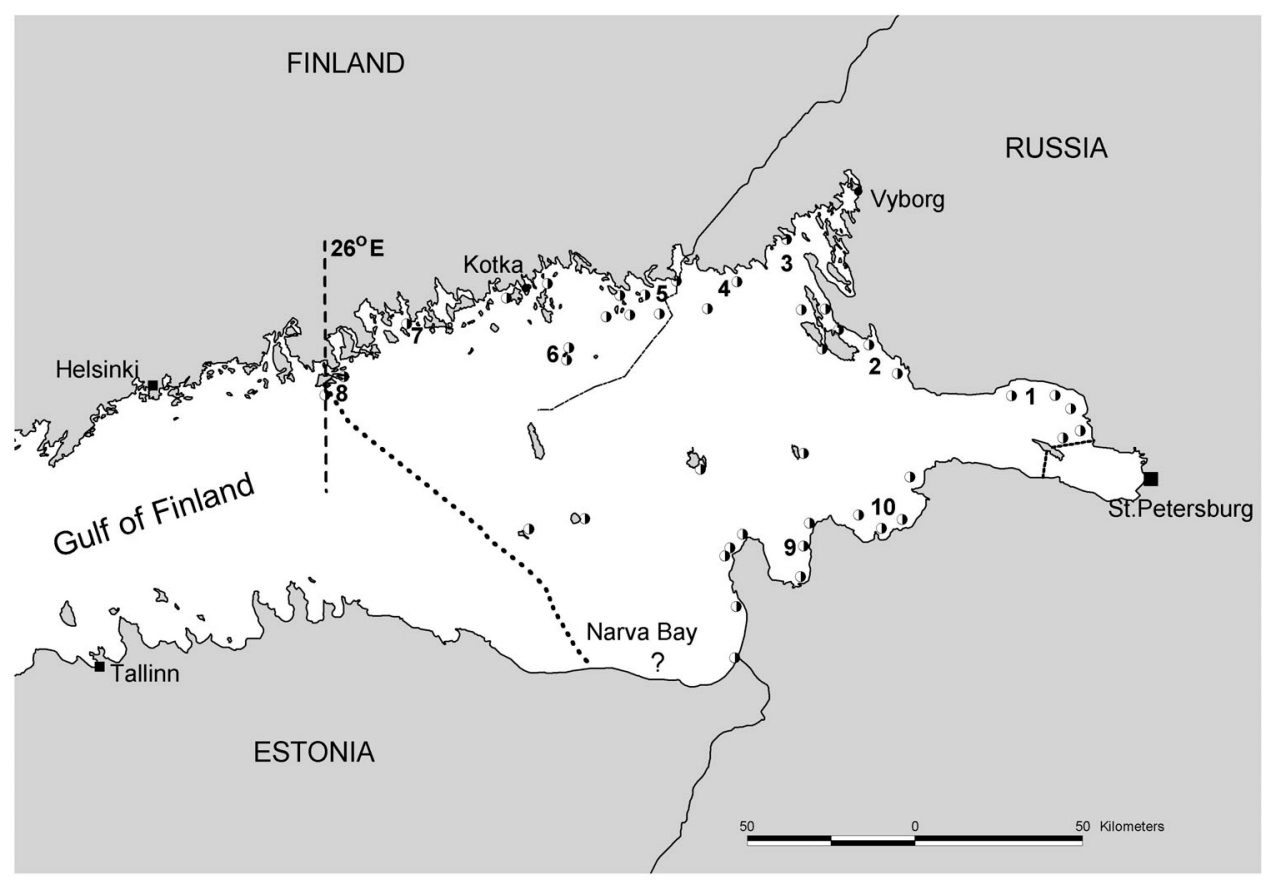

Fig. 1. The study areas in the eastern Gulf of Finland (the distribution of D. polymorpha is shown with circles): 1 -Repino, 2 - Primorsk, 3 -Vyborg, 4 -Bolshoj Fiskar Island, 5 -Santio, Ulko-Tammio, Suuri-Vasko, 6 - Haapasaari Archipelago, 7 - Lovisa Bay, 8 - Pellinki Archipelago, 9 - Luga Bay, 10 - Koporsky Bay. - the sites where D. polymorpha was found by us.

of PVC plastic, breaks, and other material. In five sites of Luga Inlet, Santio Island, Haapasaari Archipelago, and Lovisa Bay from 3 to 6 AR-modules were deployed at a depth of 4-7 $\mathrm{m}$. The duration of each experiment was 1-2 years. The abundance of spat, the replenishment intensity of the local settlements, and the growth rate of the youngest generations (age $0+$ to $1+$ ) were studied this way in natural conditions. Young mussels were measured to the nearest $0.1 \mathrm{~mm}$ using an ocular micrometer. For older mussels the growth rate was studied by measuring the so-called "annual rings" - morphological elements on shells, showing growth marks that stop during the winter period. The data on the position of the first and second (if present) annual rings are of great importance for correct determination of the age of larger individuals. In total, over 300 young mussels were investigated from artificial substrates.

The combination of these two methods gives the best results. It allows calibration of the values of annual ring size while avoiding errors in molluscs' age identification.

Growth rate analysis was made for five local populations dispersed widely in both the Finnish and Russian parts of the Gulf of Finland. For comparison 
mussels from the Severnaya Dvina River (Arkhangel'sk region, world-wide northernmost locality) were analysed. For this goal 315 mussels from various local settlements representing the actual structure of each local population (meaning all age and size groups in natural proportion) were examined. Individual age was identified by studies of the external shell morphology. About 1600 annual ring measurements were taken and analysed. The mussels' life span in every site was determined by this method as well. Finally, the growth rate was evaluated by the reconstruction of ontogenetic growth, using the Bertalanffy equation (Bertalanffy, 1938) as follows:

$$
L_{t}=L_{\infty}\left(1-\exp ^{-k\left(t-t_{0}\right)}\right)
$$

where $L_{\infty}, k$, and $t_{0}$ are the parameters; $L_{t}$ is shell length (mm) and $t$ is age (years).

The comparison of growth curves was performed by analysing the residual dispersion (Allen, 1976). The index F-ratio/F critical (at significance level $\alpha<0.05)$ was used as a measure of distance in a growth curves classification according to Maximovich (1989). The values of the index $\mathrm{F} / \mathrm{F}_{\mathrm{cr}}<1$ show that the observed differences between the compared growth curves are random. Zebra mussels' growth rates from different habitats were classified by the cluster analysis procedure.

Plankton samples for the registration of planktonic larvae and the zebra mussels' spawning period were collected from 5-0 m depth with a vertical net with the opening of $0.05 \mathrm{~m}^{2}$ and the mesh size of $0.1 \mathrm{~mm}$ from the same sites where benthic investigations were carried out.

\section{RESULTS}

\section{Distribution}

The zebra mussels are now dispersed along the northern coast of the Gulf of Finland from the St. Petersburg defensive barrier (region of the town of Kronstadt) in the east to the Pellinki Archipelago (Viasholmen Island is the westernmost locality, $26^{\circ} \mathrm{E}$ ) in the west; along the southern coast they are rather common from Koporsky Bay in the east to Narva Bay in the west. Additionally, they were found at nearly every island (both Russian and Finnish) situated in the open area of the gulf (Fig. 1).

Identification of the northernmost habitat of D. polymorpha is very important for prognosticating its potential dispersal to the north. According to our original knowledge, such locality is the mouth of the Severnaya Dvina River below the city of Arkhangel'sk a few miles from the White Sea $\left(64^{\circ} 35^{\prime} \mathrm{N}-40^{\circ} 40^{\prime} \mathrm{E}\right)$. The zebra mussels have never inhabited the White Sea itself. 


\title{
Habitats
}

\section{Relation to salinity}

In the Gulf of Finland the most prosperous settlements of zebra mussels were observed on the Russian coasts at the salinity interval of 1-4.5 PSU.

In the salinity gradient the borders of the zebra mussel's penetration toward the most saline water areas and the limit of the blue mussel Mytilus edulis (trossulus) occurring in most freshwater areas almost coincide with each other. The co-distribution of these two ecologically relative species in the eastern Baltic can be called "mirror antagonistic". The western part of the Pellinki Archipelago includes both the western margin of the zebra mussel's distribution and the eastern margin of the blue mussel's area (Fig. 1).

The average annual salinity of the Gulf of Finland is approximately 5.5 PSU. This salinity can be regarded as the upper barrier for constant existence of $D$. polymorpha and the lower one for M. edulis.

\section{Relation to the substrate}

Only various kinds of hard substrates are suitable for Dreissena attachment with the bissus thread. The mussels attach to the rock, boulders, stones, or gravel, but they never settle directly on sand or mud. A hard substrate covered with fine sediment is also unsuitable for them. On a soft bottom the zebra mussel can exist on pieces of sunken wood or shells of other molluscs (for example on Anadonta sp.).

The ability of Dreissena to attach to different kinds of artificial materials (concrete, asbestos, steel, aluminum, PVC plastic, and ceramics) was tested during underwater experiments in several sites in the eastern Gulf of Finland. All these substrates were considered equally good for the zebra mussel's settling and long-term survival. Net substrates are good only for juveniles, but they do not provide enough support for the attachment of adult mussels.

\section{Relation to the depth}

Vertical distribution of the zebra mussels observed in all sites of the Gulf of Finland was $0.5-12 \mathrm{~m}$. However, mostly they occur between 3 and $6 \mathrm{~m}$, and are extremely rare deeper than $8 \mathrm{~m}$.

\begin{abstract}
Abundance
The abundance of zebra mussels depends very much on site-specific characters. In the Russian part of the Gulf of Finland, characterized mainly by a sandy bottom in the shallow water zone, the abundance is very much determined by the availability of hard substrates.

Two basic tendencies in the spatial and temporal dynamics of the zebra mussel's abundance in the Gulf of Finland can be described as follows:

- gradual decrease in the east-west direction (along the salinity gradient); and

- stable increase from year to year during the whole period of observations.
\end{abstract}


In 1996 the most prosperous settlements in the Gulf of Finland with densities of 100-200 ind. $\mathrm{m}^{-2}$ were found in the Primorsk area, in Luga Bay, and in Narva Bay (Russian side). In Finland the abundance of the zebra mussel was much lower at the same time. It fell in the east-west direction from the maximum values of 5-8 ind. $\mathrm{m}^{-2}$ near the Russian-Finnish border to 1 ind. $5-10 \mathrm{~m}^{-2}$ in the area near Vehkalahti and Hamina and to 1 ind. $100 \mathrm{~m}^{-2}$ west from the town of Kotka in Lovisa Bay and Pellinki (Välipakka et al., 1997).

In 2002 the abundance of the zebra mussels in SE Finland was two orders of magnitude higher than first found. At the easternmost islands (Santio, UlkoTammio, Suuri-Vasko) it had reached values of 760-1100 ind. $\mathrm{m}^{-2}$ (average 240 ind. $\mathrm{m}^{-2}$ ). In Lovisa Bay the abundance was 130 ind. $\mathrm{m}^{-2}$, mainly thanks to younger generations.

\section{Reproduction}

Planktonic larvae of zebra mussels (veliger and veliconch) were observed in plankton samples from the beginning of August (in Luga Bay from July) to the middle of September. The maximum density of 20 ind. $\mathrm{m}^{-3}$ was registered in the Primorsk area in Russia. In the Finnish waters they are less abundant.

However, spat settling on AR-modules was found every year, which demonstrates regular replenishment of the population with juveniles. The amount of spat settled varied greatly from site to site and from year to year in the range 4-770 ind. $\mathrm{m}^{-2}$. The summer season of the year 1996 was abnormally cold and it was most unlucky for zebra mussel reproduction - the juveniles were found in singles and not on every site of the observations. The maximum abundance of the spat was registered in Luga Bay in season of the year 1992. During the usual period of the AR-modules check (end of September), the spat varied in size from 0.6 to $2.3 \mathrm{~mm}$, which shows that spat settling (and spawning as well) is rather extended in time.

\section{Population structure}

Just after invading a new area as a result of the drifting of planktonic larvae, the new-born settlement will consist of only one generation of mussels until the reproduction of new immigrants becomes successful and effective. Such a situation was observed at the beginning of the zebra mussel's invasion into the Gulf of Finland (Antsulevich \& Lebardin, 1990; Välipakka et al., 1997).

The structure of the D. polymorpha population from various localities in the Gulf of Finland differs very substantially. All size (and age) classes can be found only in settlements from the Russian part of the gulf and on the easternmost sites of Finland. The populations from these regions are characterized by regular annual replenishment by juveniles. However, the proportion between the generations within the local settlements is often abnormal, which demonstrates that "lucky" and "unlucky" years exist for mussel reproduction. To the west, from Kotka along the Finnish coast, full rows of size and age classes have never been observed. 
Instead we can follow a regular and complete dropping out of some generations. Such incomplete $D$. polymorpha populations occur in various localities of Finland.

The westernmost settlements of Dreissena in Finland (in the area from Kotka to the Pellinki Archipelago), as observed in 1996, were characterized by a further reduction of the number of generations in the local population. The range of variation of the zebra mussel sizes in this large area is only $14.0-18.4 \mathrm{~mm}$. Dreissena was very rare in all this water area, and all individuals belonged to one generation from the year 1992. Evidently the western part of the Finnish Dreissena population actually consists of immigrants from other localities, and their sexual reproduction is not yet effective enough because of insufficient density of the mussels. By now the best conditions for effective reproduction in Finland can be found in the easternmost area.

\section{Growth}

The growth rate of molluscs reflects integrally their general life conditions in a certain habitat. The spat settling and development were investigated on ARmodules. In the middle of September the settling of pelagic larvae of Dreissena to the substrate is normally completed. By that time, the swing of variation of spat size from various localities of the Gulf of Finland is already quite significant from 0.5 to $2.3 \mathrm{~mm}$. This is caused by the fact that some specimens have settled several weeks earlier.

The first annual ring (shell size from settling to winter stop of growth) appears on shells of $0+$ age juveniles of $0.6-5.4 \mathrm{~mm}$ length (Table 1). The size of oneyear-old molluscs (age from settling to September of the next year) was found to be in the range $2.2-7.9 \mathrm{~mm}$. The knowledge of the zebra mussel's growth rate potential in the first 1-2 years of life is very useful for the identification of annual rings in older mussels, because the first annual ring in larger specimens can often be damaged by erosion of the shell's top.

Basic measurements and calculations for growth rate analysis are presented in Table 1 for five local settlements in the Gulf of Finland and for one from the Severnaya Dvina (Arkhangel'sk). The maximum observed life duration of the zebra mussels from the Gulf of Finland varies from 8 years (Santio Island) to 10 years (Bolshoj Fiskar Island); in the area of Arkhangel'sk it was registered as 7 years.

The maximum observed shell length in the studied settlements of the Gulf of Finland was 20.4-24.2 mm; the same for the area of Arkhangel'sk was $25.3 \mathrm{~mm}$ (Table 1). It is evident that the growth rate of mussels from the Arkhangel'sk area is much higher in every age group than that of mussels from the Gulf of Finland area. The trend of slower growing local populations to have a longer life duration (and conversely) can be followed as well (Table 1).

Graphically the growth rate can be described by growth curves (Fig. 2). The growth curve of molluscs from the area of Arkhangel'sk (No. 6) is definitely placed outside those of the Gulf of Finland. The growth curves of mussels from the Gulf of Finland (1-5) are dispersed closely to one another; the difference 


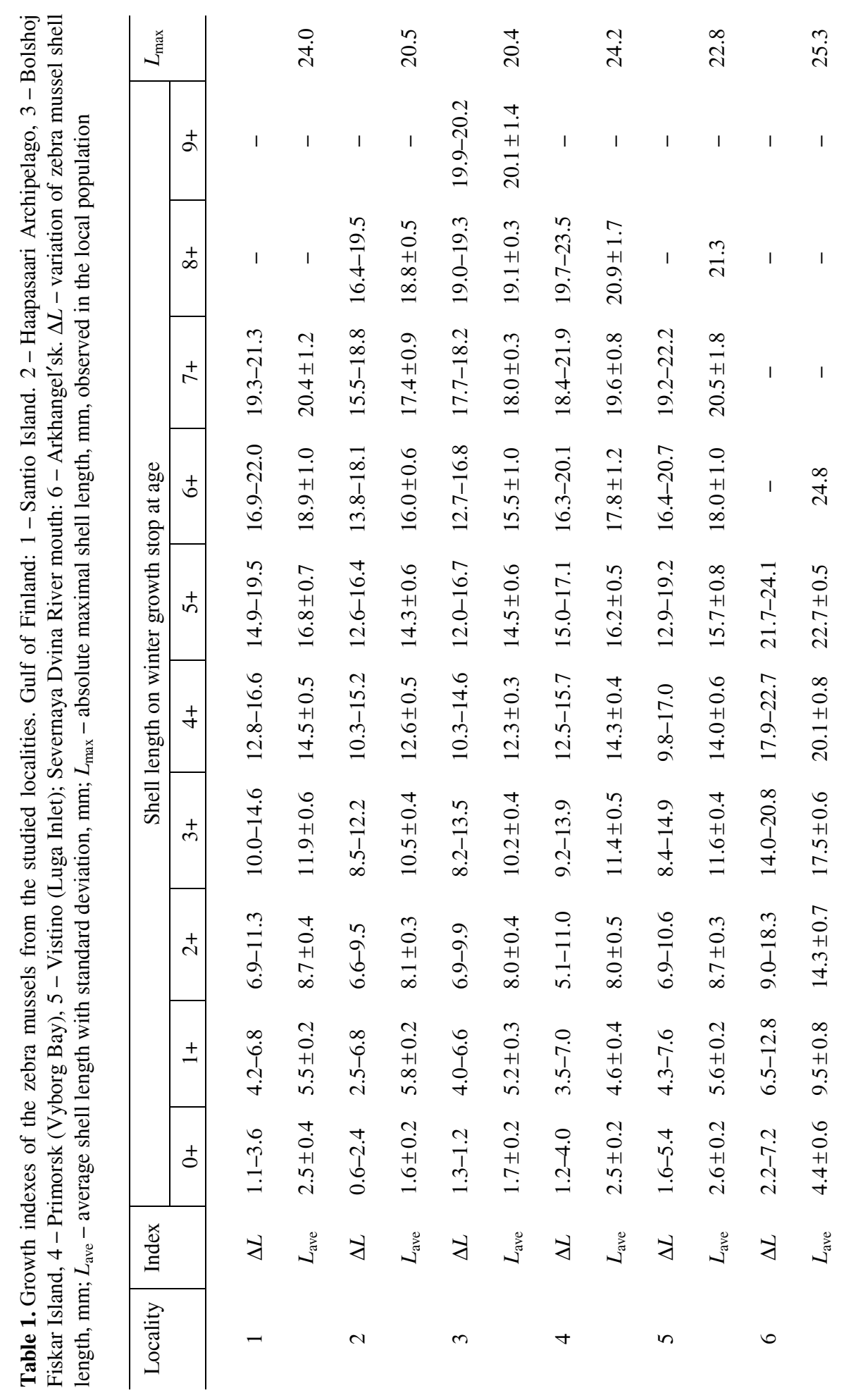


among them is often within the frames of error bars. Just for illustration, the growth curve of the zebra mussels from Tsimlyansk Reservoir (the Volga River catchment area, south of Moscow), taken from the paper of Miroshnichenko (1990), is also displayed in (Fig. 2).

Cluster analysis was used to compare the growth curves and to classify all six local zebra mussel populations by the growth rate of molluscs (Fig. 3). The separation of locality 6 (Severnaya Dvina River, Arkhangel'sk) is quite evident. The other five localities, dispersed in the Gulf of Finland, are much more similar. However, they can be reliably divided into two clusters including localities 1, 4, and 5 and 2 and 3 . The first cluster is represented by coastal local populations of Santio Island and Primorsk (Vyborg Bay) and Vistino (Luga Inlet), where the mussels' growth rate was somewhat higher and life duration somewhat shorter. The second cluster consisted of the open sea island settlements of Haapasaari and Bolshoj Fiskar, where the lowest growth rate and longest life duration of D. polymorpha were registered (Fig. 3).

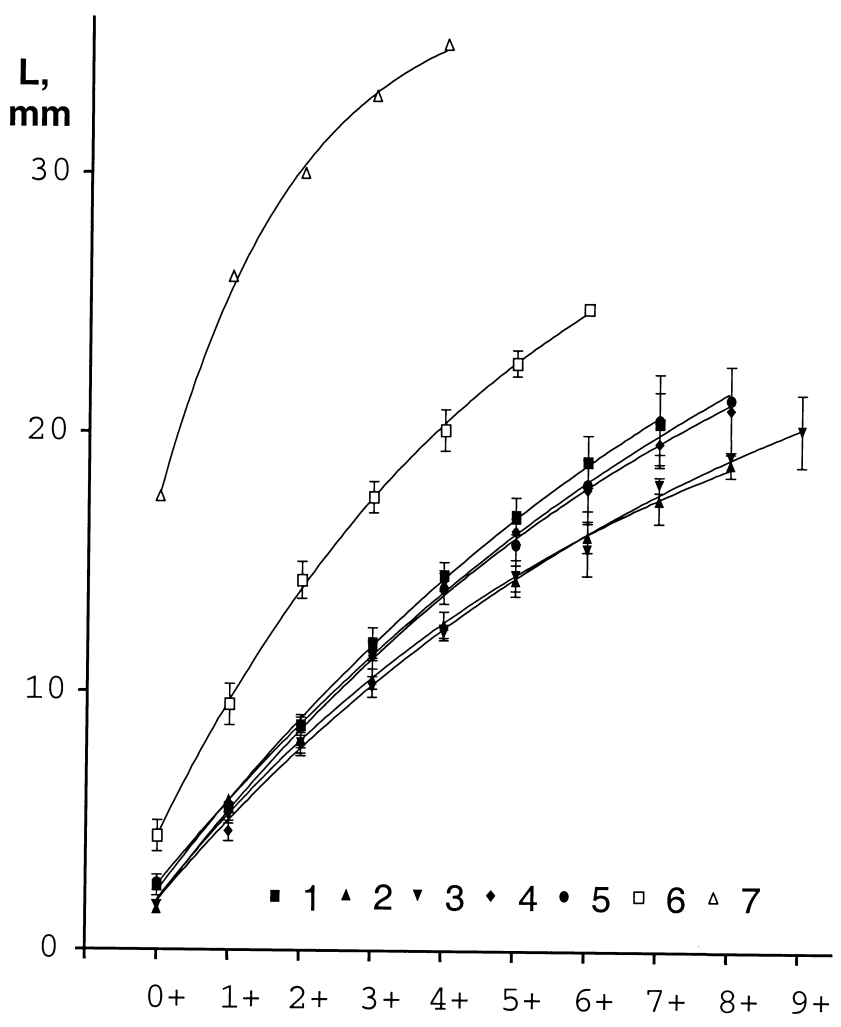

Age, years

Fig. 2. Shell length growth curves of the zebra mussels from various habitats. Gulf of Finland: 1 - Santio Island, 2 - Haapasaari Archipelago, 3 - Bolshoj Fiskar Island, 4-Primorsk (Vyborg Bay), 5 - Vistino (Luga Inlet); Severnaya Dvina River mouth: 6-Arkhangel'sk; 7 - Tsimlyansk Reservoir (Volga River catchment area, south of Moscow). 


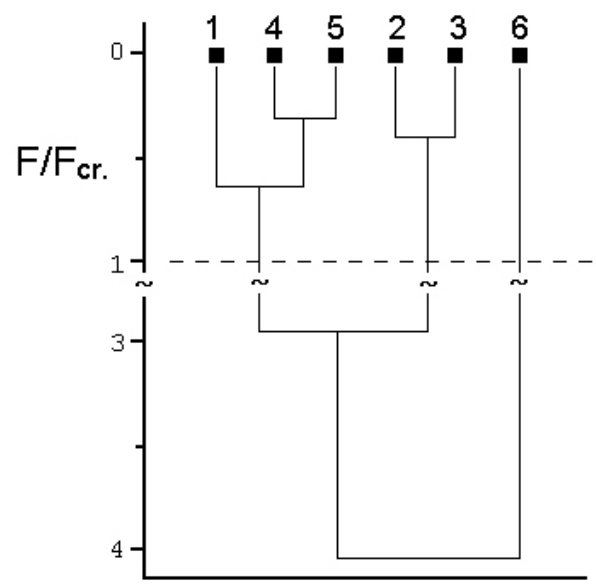

Fig. 3. Dendrogram of the growth curves comparison of the zebra mussels from different sites. Gulf of Finland: 1 - Santio Island, 2 - Haapasaari Archipelago, 3 - Bolshoj Fiskar Island, 4 - Primorsk (Vyborg Bay), 5 - Vistino (Luga Inlet); Severnaya Dvina River mouth: 6 - Arkhangel'sk. Measure of distance - ratio $\mathrm{F} / \mathrm{F}_{\mathrm{cr}}$, where $\mathrm{F}_{\mathrm{cr}}$ is critical value of $\mathrm{F}$-distribution $(\alpha<0.05)$.

One of the important characteristics of the local population is the maximum shell size. Along the northern coast of the Gulf of Finland this character increases very notably from the western margin of the zebra mussels distribution (in Finland) to the eastern one (in Russia) as follows: $18.4 \mathrm{~mm}$ in the Pellinki Archipelago, $20.5 \mathrm{~mm}$ at Haapasaari, $24.0 \mathrm{~mm}$ at Santio, $24.2 \mathrm{~mm}$ at Primorsk, and $31.5 \mathrm{~mm}$ at Repino.

The specimen with the shell length of $31.5 \mathrm{~mm}$ collected at Repino (St. Petersburg region) is the largest one ever found in the Gulf of Finland. Evidently, in this area the zebra mussels have the best living conditions within the gulf.

\section{DISCUSSION}

During almost a decade of regular observations of the zebra mussel in the Gulf of Finland, the area of its distribution in this gulf and within the eastern Baltic Sea has not enlarged. So the distribution data reported earlier (Välipakka et al., 1997) are still valid. D. polymorpha is distributed from Kronstadt (St. Petersburg region) in the east to the Pellinki Archipelago in the west, including offshore archipelagos and islands (Fig. 1). In the entire Baltic Sea, D. polymorpha inhabits the estuaries of all significant rivers and disappears in the direction of the salinity increase (Järvekülg, 1979; Leppäkoski, 1984; Antsulevich \& Chiviliov, 1992; Jansson, 1994; Gollasch \& Leppäkoski, 1999). We may speak about an "estuarine type" of zebra mussel distribution in the Baltic. 
This species is absent in Finnish coastal waters from the Pellinki Archipelago to Turku, in the Archipelago Sea, and in the Bothnian Bay. This means that zebra mussels have met their natural limits of dispersal, which is caused mainly by the salinity barrier, estimated at approximately 5.5 PSU. The distribution of zebra mussels along the Estonian coast is still unknown. We consider that Dreissena is common in the whole eastern half of Narva Bay and it disappears to the west due to increasing salinity, most probably somewhere near the town of Kohtla-Järve traverse.

For the evaluation of its potential dispersal to the north, the northernmost locality of $D$. polymorpha's actual area must be known exactly. There are many discussions, errors, and misunderstandings on this question in the literature (Strayer, 1991; Jansson, 1994; Starobogatov, 1994). From our knowledge, such a point is the Severnaya Dvina River mouth, downstream from the city of Arkhangel'sk. It is just at Dvina Bay of the White Sea. However, zebra mussels have not penetrated into the White Sea itself. Despite such a northern position, the hydrological conditions at the mouth of the Severnaya Dvina River are indeed not rigorous. The average temperature of water in the Severnaya Dvina mouth in the summertime is $16.5^{\circ} \mathrm{C}$, the average temperature in July (the warmest period) is $18.2^{\circ} \mathrm{C}$, and the maximum water temperature reported is $25^{\circ} \mathrm{C}$ (Zotin \& Mikhailov, 1965). In comparison with these parameters, the thermal conditions on the northern coast of the Gulf of Finland are much more unfavorable for the zebra mussels' existence.

The note of Jansson (1994) that in Russia the zebra mussel occurs as far north as Murmansk (the coast of the Barents Sea) seems to be erroneous, which can bring a misunderstanding in prognostic estimation of D. polymorpha's potential distribution. D. polymorpha is also known under the name "freshwater mussel", which reflects well its general relation to salinity. For D. polymorpha from the Caspian basin, the optimal salinity was determined as 0-2; pessimal salinity as 3-8, and lethal one as 12-14 PSU (Atlas, 1968; Starobogatov, 1994). Average salinity of 5-5.5 PSU is considered here to be the highest limit for its sustainable existence in the Gulf of Finland.

"Mirror antagonistic" co-distribution of zebra and blue mussels in the salinity gradient, which was described above in the Gulf of Finland, could be quite common for the whole Baltic when these two species co-occur. A similar situation with the contact of two species was registered in the Gulf of Riga and in Visla Bay between the isohalines of 5 and 6 PSU. Short- or long-term fluctuations of this environmental factor will induce displacements in both species' spatial distribution (Aristova, 1965; Järvekülg, 1979).

The density of the zebra mussels observed in 1996 (Välipakka et al., 1997) increased in SE Finland two orders of magnitude after seven years passed, and reached at the easternmost islands maximum values of 760-1100 ind. $\mathrm{m}^{-2}$. The same level of $D$. polymorpha abundance increase was reported from the Russian part of the Gulf of Finland (Panov et al., 2002). During the last few years, D. polymorpha became the dominant species of hard bottom communities in SE Finland. 
Evidently, the infestation of the Gulf of Finland with the zebra mussel has occurred naturally by a drift of planktonic larvae. Most probably the occupation of the Gulf of Finland by D. polymorpha started from Narva Bay in the 1940s. Anyway in 1937 it was already reported from the lower part of the Narva River (Sepp, 1937), but at the same time it was not found in Narva and Luga bays after careful investigations of coastal zones (Titowa, 1937). Probably it existed in Narva Bay several decades before it was actually discovered. Transport of adult molluscs by boats could also be possible, but insignificant. Probably the process of the zebra mussel's penetration into Finnish waters from adjacent areas is still going on. However, the population of D. polymorpha in SE Finland is already able to reproduce itself successfully. In easternmost areas of Finland the reproduction of domestic zebra mussels can be considered effective. These areas have become the centres of this species' dispersal in Finland.

D. polymorpha is a warm water species, but well tolerant of cold winters and ice cover except of freezing of the mussels themselves. Thermal conditions in the Gulf of Finland are obviously not favourable for the zebra mussel. This is confirmed by a smaller maximum size and much lower growth rate (parameters controlled by the temperature) of the mussels from the Gulf of Finland in comparison with southern populations (Starobogatov, 1994).

Evidently, the depth does matter for D. polymorpha. Not directly, but through other depth-dependent environmental factors, for example, a scratch of the mussels out by ice from the first 1-2 $\mathrm{m}$. The decline of zebra mussels deeper than $8 \mathrm{~m}$ can be explained by intensification of their main negative environmental factors - increasing salinity and decreasing temperature, typical of the Gulf of Finland water column - and probably by accumulation of fine sediments on substrates, preventing the attachment of molluscs with a byssus thread. In other areas, $D$. polymorpha can be abundant on the water surface $(0.1-0.5 \mathrm{~m})$ to a depth of 20-25 m and can even reach a depth of 55-60 m, as it was reported from Lake Constance (Bodensee) (Walz, 1973).

Even the maximum values of abundance observed in the Gulf of Finland are notably lower than those reported from the southern parts of D. polymorpha's distribution area. For example, in the Great Lakes the abundance of the zebra mussel in Saginaw Bay was 82000 ind. $\mathrm{m}^{-2}$ just 5-6 years after introduction; in the Szczecin Lagoon an average density of 114000 ind. $\mathrm{m}^{-2}$ was registered (Wiktor, 1969; Anon., 1994). However, in many sites of the Gulf of Finland the zebra mussel has become the dominant species on the hard bottom, where it is the only sessile mollusc and it is a successful substitute for the blue mussel in the same empty ecological niche.

The reproduction of the zebra mussel in the Gulf of Finland has "lucky" and "unlucky" years, which correspond approximately to abnormally cold (as 1996) and abnormally warm (as 1997) summer seasons. The real effectiveness of mussel reproduction can be better estimated by its final result - the settling of juveniles and their attachment to substrate. The year 1996 with a cold summer brought very insignificant replenishment to the zebra mussel population in Finnish waters. The 
generation of 1997, a year with a very warm summer, was quite the contrary. It was the most abundant among those of the last several years. According to our research, the previous successful generation like this was registered from the season of 1992. A similar lack of some generations was described also in the Russian part of the Gulf of Finland (Panov et al., 2002).

The growth rate of $D$. polymorpha in the Gulf of Finland is rather low in comparison with mussels of this species from other habitats, even lower than in the Severnaya Dvina River mouth. It is probably the lowest worldwide. For example, in the Uchinsk reservoir (close to Moscow) the maximum size of individuals settled in the current year can reach $17 \mathrm{~mm}$ in the first winter and $26 \mathrm{~mm}$ in the second winter (L'vova-Kachanova, 1972) in comparison with $6 \mathrm{~mm}$ and $7.6 \mathrm{~mm}$, respectively, observed in the Gulf of Finland. The size difference between the average specimens of the same age from the Gulf of Finland and those from other habitats is demonstrated in Fig. 4. The size of the largest zebra mussels from other parts of its area is usually over $30-35 \mathrm{~mm}$ and often reaches $45 \mathrm{~mm}$ (Atlas, 1968; Starobogatov, 1994). The maximum size of D. polymorpha across a distance of $190 \mathrm{~km}$ on the same latitude (Repino-Primorsk-SantioHaapasaari-Pellinki) decreases in the east-west direction from 31.5 to $18.4 \mathrm{~mm}$. In Finland, especially in the western part of the zebra mussels' area (KotkaPellinki region), we may speak about a dwarfed form of D. polymorpha, which is two times smaller than the normal form.

We compared the integral final result of the group growth, by comparing growth curves, and this result is evident. However, the knowledge of the nature of existing differences (seasonal day-degrees sum, maximum and minimum

(a)
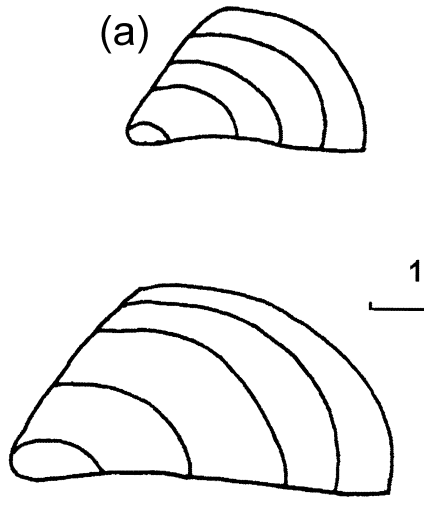

(c) (b)

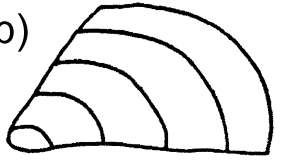

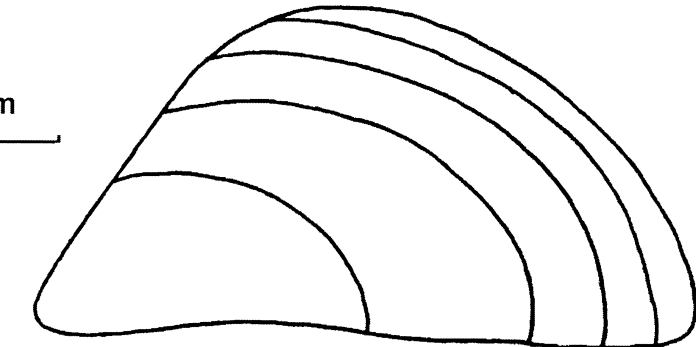

(d)

Fig. 4. Average zebra mussel specimens of the same age (4+) from the Gulf of Finland (a and b) and other habitats (c and d). a - Haapasaari Archipelago; b - Santio Island; c - Severnaya Dvina River mouth (Arkhangel'sk); d - Tsimlyansk Reservoir (south of Moscow). 
temperatures per season, amount and quality of the available food and conditions of its transportation, local water currents and turbulence, physiological and genetic peculiarities of the local populations, etc.) is certainly incomplete. In hydrologically similar water bodies the temperature alone is able to predict the growth rates of the zebra mussels quite well (Smit et al., 1992). However, in coastal waters of Finland the decrease in growth rate is caused by the combined impact of two negative factors - high salinity (4.5-5 PSU) and low summer temperature. The latter is a result of typical summer upwellings in this part of the Gulf of Finland, due to which surface water temperature may drop down to $6-8{ }^{\circ} \mathrm{C}$ several times during the summer season.

The penetration of the zebra mussel as far to the west as the Helsinki coastal area and even farther is not expected in current hydrological conditions because of high salinity limitation (salinity more than 5-5.5 PSU). Infestation of continental waters of South Finland by D. polymorpha seems to be difficult, but possible. There the mussels can meet more favourable fresh and warm water, but low $\mathrm{pH}$ values and insignificant water hardness (low concentration of calcium), peculiar to the major part of Finnish freshwater bodies.

Within the Finnish coastal waters better life conditions (at least thermal ones) for zebra mussels can be observed in Lovisa Bay, where the water warms up substantially (additionally 3-5 degrees) due to the nuclear power plant cooling system discharge. Lovisa Bay is "protected" from larvae drift of the eastern mother populations by the numerous islands of the coastal archipelago, where the drifting larvae settle. However, both the adult mussels (of the generation of 1997) and the juveniles (from the season 2002) were found inside Lovisa Bay. If the new settlement is successfully established in the next years, the planktonic larvae of the zebra mussel can penetrate inside the pipes of water-supply and cooling systems. There they will find suitable substrates, good oxygenation, and a constant stream with food particles (phytoplankton and suspended organic matter).

D. polymorpha is a very dynamic and ecologically plastic species. During the last two centuries it has created many surprises for mankind. This may happen in the Gulf of Finland area as well, therefore a constant monitoring programme for this species is needed.

\section{ACKNOWLEDGEMENTS}

The authors are very grateful to the Southeast Finland Regional Environmental Center (Kouvola) for the support and to Drs. Jouni Taskinen and Nicolaj Maximovich for fruitful discussions. 


\section{REFERENCES}

Allen, R. L. 1976. Method for comparing fish growth curves. N. Z. J. Mar. Freshwater Res., 10, 687-692.

Anon. 1994. The ecological approach to the zebra mussel infestation in the Great Lakes - a progress report from the Co-operative Institute for Limnology and Ecosystems Research and the Great Lakes Environmental Research Laboratory. NOAA, Ann Arbor, Michigan.

Antsulevich, A. E. 1994. Artificial reefs project for improvement of water quality and environmental enhancement of Neva Bay (St.-Petersburg County Region). Bull. Marine Sci., Univ. Miami, 55(2), 1191-1194.

Antsulevich, A. E. \& Chiviliov, S. M. 1992. Modern state of Luga Inlet benthic fauna of the Gulf of Finland. Vestn. St.-Petersb. Univ., Biol., Ser. 3, 3(17), 3-7, 110 (in Russian).

Antsulevich, A. E. \& Lebardin, M. V. 1990. "Wandering shell” Dreissena polymorpha (Pall.) is close to Leningrad. Vestn. Leningr. Univ., Biol., Ser. 3, 4(24), 109-110 (in Russian).

Antsulevich, A. E., Laihonen, P. \& Vuorinen, I. 2000. Employment of artificial reefs for environmental maintenance in the Gulf of Finland. In Artificial Reefs in European Seas (Jensen, A. C., Collins, K. J. \& Lockwood, A. P. M., eds.), pp. 319-329. Univ. of Southampton, UK, Kluwer Acad. Publ.

Aristova, G. I. 1965. The benthos of the Visla Bay. Issled. Kursk. Vislinsk. zaliv. (Kaliningrad), 14, 40-49 (in Russian).

Atlas of Invertebrates of the Caspian Sea. 1968. Pishchevaya Promyshlennost', Moscow (in Russian).

Bertalanffy, L. V. 1938. A quantitative theory of organic growth. Hum. Biol. (Baltimore), 10, 181-213.

Gollasch, S. \& Leppäkoski, E. (eds.). 1999. Initial risk assessment of alien species in Nordic coastal waters. Nord, 8.

Jansson, K. 1994. Alien species in the marine environment. Introductions to the Baltic Sea and the Swedish west coast. Swed. Env. Prot. Ag., Rep. 4357.

Järvekülg, A. 1979. Bottom Fauna of the Eastern Part of the Baltic Sea. Valgus, Tallinn (in Russian).

Leppäkoski, E. 1984. Introduced species in the Baltic Sea and its coastal ecosystems. Ophelia, Suppl. 3, 123-135.

L'vova-Katchanova, A. A. 1971. On the role of Dreissena polymorpha Pallas in processes of selfpurification of the water of Uchinskoye reservoir. In Complex Investigations of Water Reservoirs, 1, pp. 196-203. Moscow Univ. Press (in Russian).

L'vova-Kachanova, A. A. 1972. Growth and longevity of Dreissena polymorpha (Pall.). In Complex Investigations of the Caspian Sea, pp. 74-82. Moscow (in Russian).

Maximovich, N. V. 1989. Statistical comparison of growth curves. Vestn. Leningr. Univ., 3(4), 18-25 (in Russian).

Mikheev, V. P. 1967. Filtration nutrition of the Dreissena. In Questions of the Ponds Fish-farming, 15, pp. 117-129. Pishchevaya Promyshlennost', Moscow (in Russian).

Miroshnichenko, M. P. 1990. Growth, production and meaning in Tsimlyansk reservoir fish food resources of Dreissena polymorpha (Pallas). In Species in Area: Biology, Ecology and Productivity of Aquatic Invertebrates, pp. 141-146. Nauka Tekhn., Minsk (in Russian).

Panov, V. E., Alimov, A. F., Golubkov, S. M., Orlova, M. I., Telesh, I. V., Balushkina, E. V. \& Anokhina, L. E. 2002. Environmental problems and challenges for coastal zone management in the Neva Estuary (eastern Gulf of Finland). In Baltic Coastal Ecosystems: Structure, Function and Coastal Zone Management (Schernewski, G. \& Schiewer, U., eds.), pp. 171-184. CEEDES-Ser., Springer, Berlin.

Reeders, H. H. \& bij de Vaate, A. 1990. Zebra mussels (Dreissena polymorpha): a new perspective for water quality management. Hydrobiologia, 200/201, 437-450.

Reeders, H. H., bij de Vaate, A. \& Noordhius, R. 1993. Potential of the zebra mussel (Dreissena polymorpha) for water quality management. In Zebra Mussels: Biology, Impacts, and Control (Nalepa, T. F. \& Schloesser, D. W., eds.), pp. 439-451. Lewis Publ., Boca Raton, FL.

Sepp, L. 1937. Dreissena polymorpha Pall. Narva jõe alamjooksul. Eesti Loodus, 5, 155-157. 
Schloesser, D. W., bij de Vaate, A. \& Zimmerman, A. 1994. A bibliography of "Dreissena polymorpha in European and Russian waters: 1964-1993". J. Shellfish Res., 13(1), 243-267.

Smit, H., bij de Vaate, A. \& Fioole, A. 1992. Shell growth of the Zebra mussel (Dreissena polymorpha (Pallas)) in relation to selected physicochemical parameters in the Lower Rhine and some associated lakes. Arch. Hydrobiol., 124(3), 257-280.

Smit, H., bij de Vaate, A., Reeders, H. H., van Nes, E. H. \& Noordhuis, R. 1993. Colonization, ecology, and positive aspects of zebra mussels (Dreissena polymorpha) in The Netherlands. In Zebra Mussels: Biology, Impacts, and Control (Nalepa, T. F. \& Schloesser, D. W., eds.), Chapter 3, pp. 55-77. Lewis Publ., Boca Raton, FL.

Starobogatov, J. I. (ed.). 1994. Freshwater Zebra Mussel Dreissena polymorpha (Pall.) (Bivalvia, Dreissenidae) Systematics, Ecology, Practical Meaning. Moscow, Nauka (in Russian).

Strayer, D. L. 1991. Projected distribution of the zebra mussel, Dreissena polymorpha, in North America. Can. J. Fish. Aquatic Sci., 48(8), 1389-1395.

Titowa, A. 1937. Quantitative und qualitative Einschätzung der Hydrofauna der Küstenzone der Kopor-, Luga und Narva-Bucht des Finnischen Meerbusens. Sci. Notes Leningrad State Univ., 15, 155-170 (in Russian).

Välipakka, P., Antsulevich, A. E., Vaittinen, J. \& Taskinen, J. 1997. The zebra mussel (Dreissena polymorpha) - a new important element in the fauna of the Gulf of Finland. In Proc. of the Final Seminar of the Gulf of Finland Year 1996 (Sarkkula, J., ed.). Suom. ymp. mon., Helsinki, 257.

Valovirta, I. \& Porkka, M. 1996. The distribution and abundance of Dreissena polymorpha (Pallas) in the eastern Gulf of Finland. Mem. Soc. Fauna Flora Fenn., 72, 63-78.

Walz, N. 1973. Untersuchungen zur Biologie von Dreissena polymorpha Pallas in Bodensee. Arch. Hydrobiol., 42(3/4), Suppl., 452-482.

Wiktor, J. 1969. Biologia Dreissena polymorpha (Pall.) i jei ecologiczne znaczenie w Zalewie Szczecinskim. Stud. Mater. Morski. Inst. Ryb Gdynia, Ser, A, 5, 1-88.

Zotin, M. I. \& Mikhailov, V. N. (eds.). 1965. Hydrology of the Severnaya Dvina River Mouth Area. Gidrometeoizdat, Moscow (in Russian).

\section{Kuidas läheb rändkarbil Soome lahes?}

\section{Alexander E. Antsulevich, Pentti Välipakka ja Juhani Vaittinen}

Rändkarpi (Dreissena polymorpha) leiti Soome lahes esimest korda alles 1990. aastal. Tema levikut, arvukust, ökoloogiat ja kasvukiirust uuriti akvalangiga sukeldudes. Noorte ja täiskasvanud karpide kasvukiirus selgitati nii otseste vaatlustega looduses kunstlikul aluspinnal kui ka aastaringide abil. Analüüsiti Soome ja Venemaa rannikumeres paikneva viie kohaliku asurkonna kasvukiirust. Leiti, et lahe lääneosas piirab rändkarbi levikut soolsustase 5\%o. Viimase aastakümne jooksul on selle karbi arvukus kasvanud ühe kuni kahe suurusjärgu võrra. Soome lahes on rändkarbi kasvukiirus tõenäoliselt maailma madalaim. 